\title{
Use of fluorescently labelled algae (FLA) to estimate microzooplankton grazing
}

\author{
Parke A. Rublee ${ }^{1}$, Charles L. Gallegos ${ }^{2}$ \\ ${ }^{1}$ Biology Department, Whitman College, Walla Walla, Washington 99362, USA \\ ${ }^{2}$ Smithsonian Environmental Research Center, Edgewater, Maryland 21037, USA
}

\begin{abstract}
The fluorescent dye 5-(4,6-dichlorotriazin-2-yl) aminofluorescein (DTAF) was used to label a small alga (Nannochloris sp.), following the protocol of Sherr et al. (1987). A rotifer (Brachionus sp.) and a small ciliate (Euplotes sp.) ingested the fluorescently labelled algae (FLA) and demonstrated saturation kinetics. A small tintinnid ingested the FLA at rates intermediate to those of the rotifer and ciliate. Fluorescent labelling of algae is a promising technique that may be used for estimating grazing rates in a manner analogous to that discribed by Sherr et al. (1987) using fluorescently labelled bacteria (FLB).
\end{abstract}

\section{INTRODUCTION}

The microbial loop hypothesis has become a focus of research in aquatic ecology over the past decade (Azam et al. 1983, Pomeroy \& Wiebe 1988). Key elements of this hypothesis include bacterial uptake of dissolved organic matter, and consumption of bacteria by nanoplankton and microplankton predators, with subsequent consumption by larger zooplankton. The hypothesis further suggests that these transfers may enhance movement of nutrients and energy to higher trophic levels because the bacteria can use organics released by excretion, 'sloppy-eating', or cell lysis which otherwise would have been lost.

One aspect of this focus has been to measure grazing within the microbial loop. This has usually involved adapting techniques used with crustacean zooplankton for use with the smaller $(<200 \mu \mathrm{m})$ larval, rotifer, and protozoan planktonic grazers. These methods generally follow the change in the prey populations and fall into 2 categories. The first is to monitor the prey population(s) under natural or varied predator densities. This can be by additions of predators (e.g. Peterson et al. 1978) or removal of predators by filtration (e.g. Ducklow \& Hill 1985) or dilution (e.g. Landry \& Hassett 1982). The second approach is to use a tracer method to follow the incorporation of prey by predators by introducing radioisotopic tags (e.g. Lessard \& Swift 1985), or analogues of the prey population such as fluorescent particles of appropriate size (e.g. Børsheim 1984,
McManus \& Fuhrman 1986). In each case, the investigator must account for prey growth and lysis during the incubation as well as predatory losses. Modifications of the basic approaches have included the use of antibiotics to alter activities of the prey or the predator (e.g. Newell et al. 1983). McManus \& Fuhrman (1988) have reviewed these methods as applied to predation on bacterioplankton and noted the advantages and disadvantages of each method.

Recently Sherr et al. (1987) described a novel tracer method of labelling bacteria with the fluorescent dye 5(4,6-dichlorotriazin-2-yl) aminofluorescein (DTAF) for use in determining protozoan grazing rates on bacteria. In this approach, cultured or natural bacterial assemblages, which are killed but remain intact during the staining process, are introduced at tracer levels into populations of grazers. After short incubation times (measurable uptake can take place in as little as $5 \mathrm{~min}$ ) the uptake of fluorescently labelled bacteria (FLB) can be determined for individual consumers.

The major advantage of using fluorescently labelled bacteria is that the food resource is 'natural' and thus reduces (although may not eliminate) concern about chemosensory selectivity associated with non-biological tracers. For example, Sherr et al. (1987) found that some ciliates and flagellates ingested FLB at rates up to 10 times the rate of ingestion of fluorescent latex microspheres. Pace \& Bailiff (1987) noted that microspheres were a suitable tracer in feeding experiments with one ciliate, a Cyclidium sp., but they did not appear to be 
suitable for all phagotrophs. They aIso noted that many literature reports of grazing rates estimated with microspheres are much lower than those determined by other methods for the same taxa. Chemosensory responses by a microflagellate to bacteria, inorganic nitrogen compounds and amino acids have been documented by Sibbald et al. (1987).

In this paper we describe the feasibility of the DTAF staining protocol (Sherr et al. 1987) to produce fluorescently labelled algae (FLA) for use in determining heterotrophic microplankton grazing rates.

\section{METHODS}

We utilized several algal species in this study. Our primary alga was a small $(3 \times 7 \mu \mathrm{m})$ Nannochloris sp. isolated from the Rhode River, Maryland, USA (salinity 14 ppt). Other isolates from Chesapeake Bay included Prorocentrum mariae-lebouriae, and Chaetoceros calcitrans. We also tested the staining protocol with several other marine and freshwater algae obtained from collections or commercial suppliers. Marine isolates were maintained on $\mathrm{f} / 2$ medium and freshwater isolates maintained on Alga-Gro (Carolina Biological Supply Co.)

The procedure used to label the algae was that of Sherr et al. (1987), except that all centrifugation steps were done at $800 \times g$ in a clinical centrifuge. Briefly, for marine algae, cells were concentrated by centrifugation, suspended in $10 \mathrm{ml}$ of phosphate-buffered saline (0.05 $\mathrm{M} \mathrm{Na}_{2} \mathrm{HPO}_{4}$ in $0.85 \% \mathrm{NaCl}$ adjusted to $\mathrm{pH} 9$ ), and incubated for $2 \mathrm{~h}$ at $54{ }^{\circ} \mathrm{C}$ with $2 \mathrm{mg} \mathrm{DTAF}$. Some algal species were incubated with stain for longer periods (see discussion below). The incubation was followed by 3 washes with the phosphate-buffered saline, resuspension in the buffer solution, and storage in the refrigerator For freshwater algae the process was the same except that all buffers were made with deionized water instead of saline solutions. For use, the stocks of FLA were resuspended with a vortex mixer, diluted to an appropriate concentration, and passed through mesh nets of 20 or $37 \mu \mathrm{m}$ openings to remove any clumped cells.

Observation of microplankton and enumeration of FLA were done with a Zeiss Universal epifluorescence microscope. Zeiss light filter set 477709 (BP 450-490 excitation filter, FT 510 beam splitter, and LP 470 barrier filter), which is usually supplied for use with fluorescein isothiocyanate and acridine orange, is also suitable for DTAF, since the excitation and emission spectra are similar for these fluorochromes. We have also used Zeiss filter sets 477716 (BP 485/20 excitation filter, FT 510 beam splitter, LP 470 barrier filter) and 477705 (BP 400-440 excitation filter, FT 460 beam splitter, LP 470 barrier filter). Filter set 477716 may be the best combination, since it eliminates chlorophyll $a$ fluorescence and reduces background fluorescence.

For observation, water samples were passed through a $5.0 \mu \mathrm{m}$ pore size black Nuclepore filter or a $8.0 \mu \mathrm{m}$ pore white cellulose acetate membrane filter, and the filter stained with rose bengal following the procedure of Baldock (1986). Filters were rinsed with several $\mathrm{ml}$ of $0.05 \mathrm{M} \mathrm{CaCl}_{2}$ solution and then mounted in $43 \%$ sucrose solution. The filter was scanned under transmitted light at $100 \times$ magnification to locate individual microplankters stained pink by the rose bengal. Magnification was then increased to $250 \times$ or $400 \times$, the transmitted light turned off and epifluorescent illumination used to count the bright green fluorescent algae within the organism.

Several types of experiments were conducted with the fluorescently stained Nannochloris isolate: first, time-course experiments to determine grazing rates;

Table 1 Alga tested for fluorescent labelling with DTAF

\begin{tabular}{|c|c|c|c|}
\hline Taxon & Size $(\mu \mathrm{m})$ & Source & Remarks \\
\hline Nannochloris sp. & $7 \times 3$ & Brackısh & Excellent uniform staining \\
\hline Chaetoceros calcitrans & $5 \times 5$ & Brackish & Uneven staining, spines damaged by centrifugation \\
\hline Prorocentrum mariae-lebouria & $17 \times 10$ & Brackish & Excellent uniform staining \\
\hline Synechococcus sp. & 2 & Marine & Excellent uniform staining \\
\hline Chroomonas sp. (UTEX LB 2000) & $2 \times 1.5$ & Marine & Uneven staining, flagella lost \\
\hline Tetraselmis suecica (UTEX LB 2286) & $11 \times 7$ & Marine & Uneven staining, flagella lost \\
\hline Thalassiosira pseudonana & $5 \times 3$ & Marine & Excellent uniform staining \\
\hline Chlorella sp. & 4 & Freshwater & Farrly uniform, bright stain \\
\hline Chlamydomonas sp. & 14 & Freshwater & Uneven stainmg, flagella lost \\
\hline Scenedesmus sp. & $35 \times 8$ & Freshwater & $\begin{array}{l}\text { Uneven staining, pigment fluorescence retained in } \\
\text { some cells }\end{array}$ \\
\hline Closterium sp. & $200 \times 30$ & Freshwater & Uneven staining \\
\hline
\end{tabular}


second, short-term experiments (30 min) to examine the relationship of grazing to concentrations of the food resource; third, short-term experiments where ratios of live and labelled Nannochloris were altered to test for selectivity. For each type of experiment, FLA were diluted from the stock solution with freshly collected water after filtering through a $\mathrm{GF} / \mathrm{C}$ glass fiber filter. Microplankton were also freshly collected from the Rhode River by gently passing water through a $20 \mu \mathrm{m}$ nitex net, backwashing into a petri dish and then handpicking individuals while viewing through a dissecting microscope. Heterotrophic microplankton were then incubated with FLA in 5 to $20 \mathrm{ml}$ filtered water in blood counting vials on a shaker table at an intermediate speed to maintain FLA in suspension. Samples were drawn onto black polycarbonate filters $(5.0 \mu \mathrm{m}$ pore size) or cellulose acetate filters ( $8.0 \mathrm{um}$ pore size) at the end of the incubation period and counted immediately.

\section{RESULTS AND DISCUSSION}

We found the preparation of FLA to be relatively simple and rapid for small algae following the protocol of Sherr et al. (1987). The Nannochloris sp. we used produced a uniform bright green fluorescent cell that was highly visible in filtered or whole water samples and easily distinguishable within microplankton cells or bodies. The algal cells were monodispersed and very little red chlorophyll fluorescence was evident in stained cells. These cells were examined and utilized over a period of up to $4 \mathrm{wk}$ with no visually apparent damage; however, the maximum length of 'shelf life' for stained algal cells is not known. We have not tried lyophilyzation or freezing for long-term storage as Sherr et al. (1987) have done with bacteria, but suspect that it would cause damage to algal cells.

There are several potential problems with DTAF staining of algal cells. First, there is some variability in staining (Table 1). A small cyanobacterium, Synechococcus sp., did stain easily as would be expected since it is prokaryotic. However, a large freshwater alga, Closterium sp., stained brightly but there was not uniform fluorescence throughout the cell. Additionally, a culture of Scenedesmus sp. exhibited some cells that were stained a uniform green and some cells that maintained part or all of their red fluorescence from pigments. Thus, longer incubation times may be required for some algal taxa. A second problem is that forms with spines or projections may be damaged by the centrifugation process. When we stained a culture of Chaetoceros calcitrans, most cells exhibited broken spines, the cells clumped badly, and in many cases whole cells were damaged. Settling or centrifugation at lower speeds might reduce this problem.

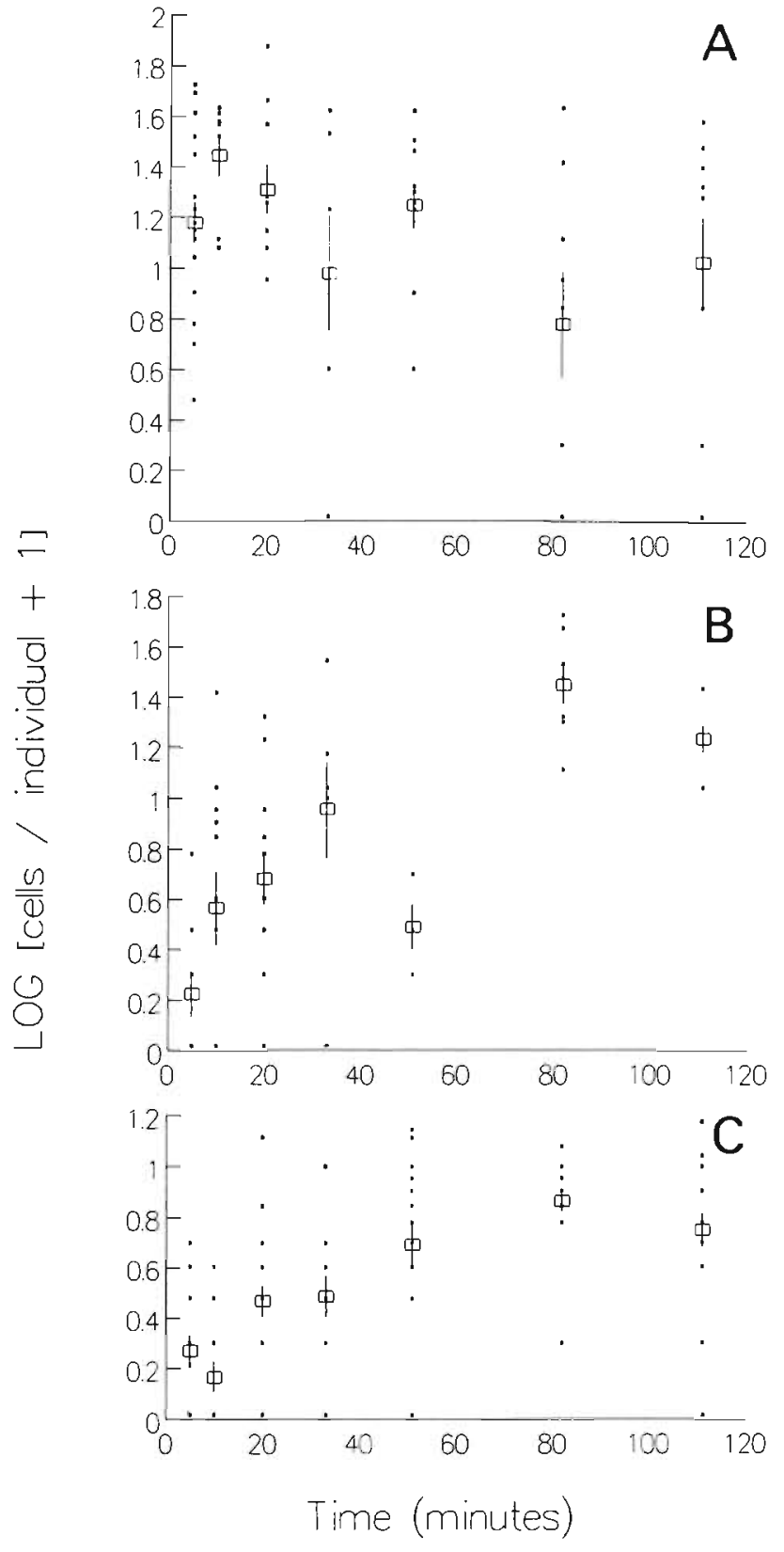

Fig. 1. Time course uptake of Nannochloris FLA by $3 \mathrm{mi}-$ crozooplankton. (A) Rotifer, Branchionus sp.; (B) tintinnid; (C) Euplotes sp. In all figures asterisks: 1 or more individuals; () mean; vertical bar: $\pm 1 \mathrm{SE}$

Grazing of fluorescently labelled algal cells was evident for all 3 heterotrophic microplankton studied over time-course experiments (Fig. 1). FLA were added at a final concentration of $4.72 \times 10^{4}$ cells $\mathrm{ml}^{-1}$, a concentration of Nannochloris that is achieved naturally in the Rhode River. Within 10 min of introducing the FLA, a rotifer (Brachionus sp., 150 to $200 \mu \mathrm{m}$ in length) averaged 30 algal cells per individual. Uptake by a small tintinnid ( $50 \mu \mathrm{m}$ in length) was less rapid, achieving a maximum uptake of about 15 to 20 cells per individual 
after 60 min. Uptake of FLA by a small ciliate, tentatively identified as a Euplotes sp. (35 $\mu \mathrm{m}$ in length) was slower still, with a maximum uptake averaging 7 cells per organism after $80 \mathrm{~min}$.

Uptake of FLA exhibited a hyperbolic relation with concentration for the rotifer and the hypotrich (Fig. 2). In both cases there was limited but measurable uptake of cells when concentrations were below about $2 \times 10^{3}$ FLA $\mathrm{ml}^{-1}$. The uptake curve rose more sharply above this concentration until saturation was reached at concentrations greater than about $5 \times 10^{4} \mathrm{FLA} \mathrm{ml}^{-1}$. Similar relations have been reported by Jonsson (1986) with oligotrichous ciliates feeding on live or inert particles over a range which includes the size of the Nannochloris used here. Rivier et al. (1985) also found a similar relationship with flagellates and ciliates grazing on bacteria, but the saturating concentrations for bacteria were much higher $\left(10^{7}\right.$ cells $\left.\mathrm{ml}^{-1}\right)$.

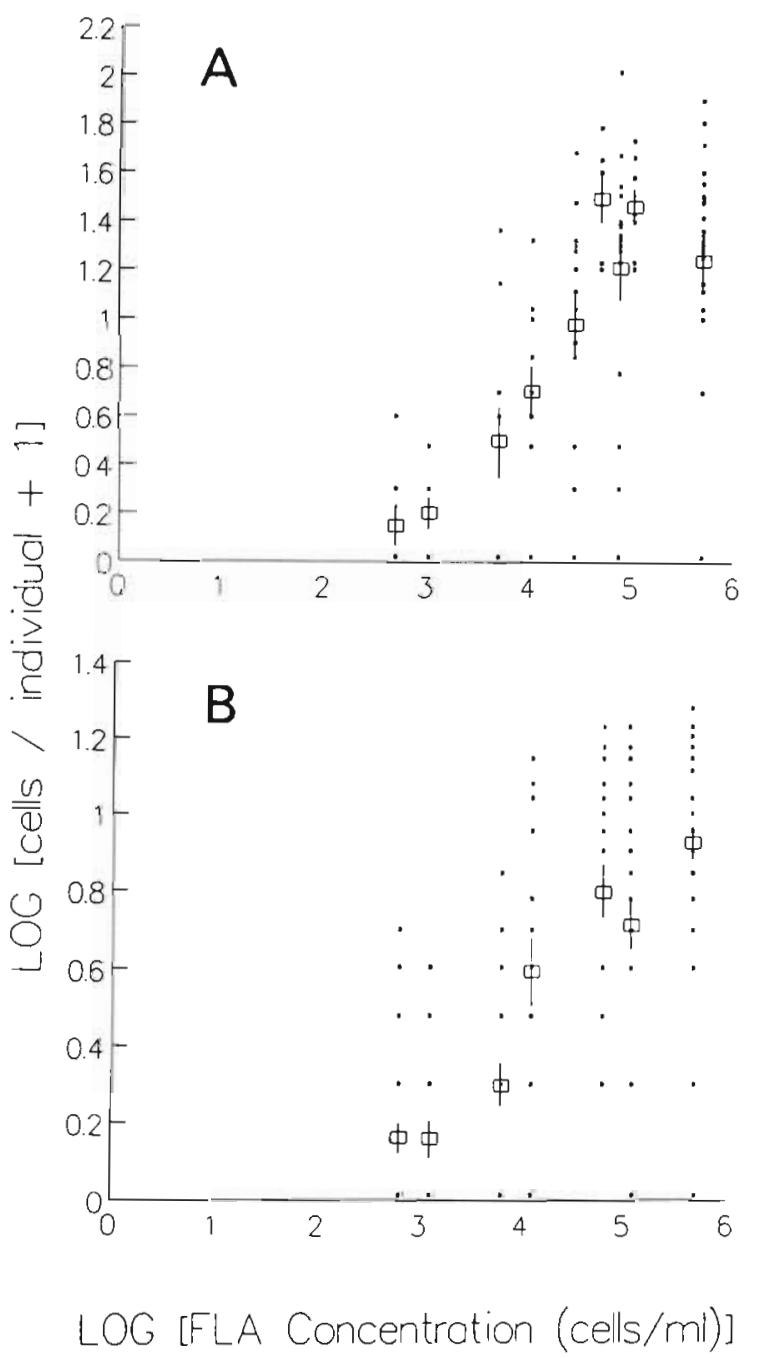

Fig. 2. Uptake of Nannochloris FLA vs concentration by 2 microzooplankton. (A) Rotifer, Brachionus sp.; (B) Euplotes sp.
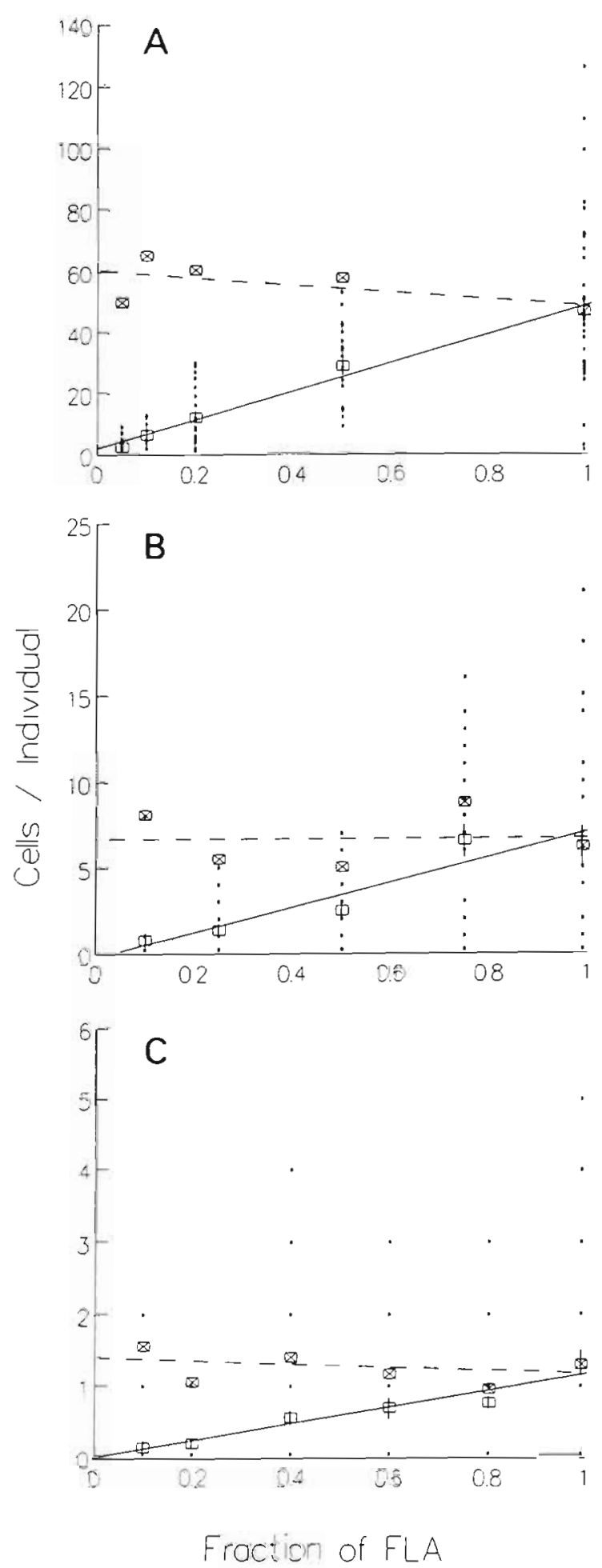

Fig. 3. Selectivity of Nannochloris FLA vs unlabelled Nannochloris cells by microzooplankton. (A) Rotifer, Branchionus sp.; (B) tintinnid; (C) Euplotes sp. Solid line: regression of FLA uptake vs fraction of FLA in the algal mixture; dashed line: regression of total algal cell uptake (cells per individual/ fraction of FLA) vs fraction of FLA 
Elimination of any selective grazing for or against the labelled cells is a distinct advantage of the FLA method. The algae are heat-killed as a result of the staining process, and if the dead cells were selectively grazed, it would lead to erroneous measurements. However, experiments with live and DTAF-stained bacteria have not suggested significant discrimination against FLB by ciliated protozoans (B. Sherr, Univ. of Georgia, pers. comm.), and selectivity was also not demonstrated in our study when the ratio of FLA to live Nannochloris sp. cells was altered while the total cell number was held constant (Fig. 3). With each of the microplankton tested, when mean uptake rates of the tracer cells are converted to total cell uptake, slopes of the regression of uptake vs fraction of labelled cells (Fig. 3) were not significantly different from zero ( $T$ test: $t=1.11,3 \mathrm{df}$, NS for Brachionus sp; $t=0.01,3 \mathrm{df}$, NS for the tintinnid; and $t=0.84,4 \mathrm{df}$, NS for Euplotes sp.). Thus, no selectivity was demonstrated.

We also conducted one experiment to test whether the fluorescently labelled Nannochloris sp. was a reasonable tracer of a natural mixed phytoplankton assemblage. In this experiment, we screened water from the Rhode River through a $20 \mu \mathrm{m}$ mesh net, and then drew $1 \mathrm{ml}$ of the filtrate onto a black $0.8 \mu \mathrm{m}$ pore Nuclepore filter. The filter was then examined under epifluorescent illumination and the number of deep red autofluorescent particles (AFP) between 2 and $15 \mu \mathrm{m}$ in length enumerated. It was assumed that these were chloroplasts and represented nanoplanktonic algal cells. FLA were added to aliquots of the $20 \mu \mathrm{m}$ mesh screened water in FLA:AFP ratios from 0.012 to 0.19 . Brachionus sp. isolated from the sample by retention on the $20 \mu \mathrm{m}$ mesh screen were added to each aliquot and incubated for $10 \mathrm{~min}$. The sample was then harvested as described previously and uptake of FLA by the rotifers determined. No selectivity of FLA or AFP's was indicated since the slope of total uptake vs fraction of labelled cells was not significantly different from zero (Fig. $4, t=0.01,3$ df, NS), Thus, Nannochloris FLA was an appropriate tracer for grazing of this fraction of our natural sample. At other sites or times, the most appropriate algal species (or mix of algal species) to be used as FLA tracers would have to be determined.

The uptake rates in our experiments can be converted to clearance rates (in $\mu$ l ind. ${ }^{-1} h^{-1}$ ) from the equation:

$$
\text { Clearance Rate }=\frac{\mathrm{IR}}{\mathrm{TC}}
$$

where $\mathrm{IR}=$ ingestion rate in cells ind ${ }^{-1} \mathrm{~h}^{-1} ; \mathrm{TC}=$ tracer cell concentration in cells $\mu l^{-1}$ (Bogdan \& Gilbert 1984). These estimated clearance rates ranged from 0 to 12,0 to 3 , and 0 to $12.5 \mu \mathrm{lind} .^{-1} \mathrm{~h}^{-1}$, respectively, for the rotifer, tintinnid, and ciliate. These values are in the lower range of clearance rates determined by a variety of methods in other studies of rotifers, ciliates, and flagellates (Table 2). These lower rates may be attributable to the method of maintaining the FLA in suspension during the incubations (shaker table rather than a more gentle plankton wheelj or the use of a single species of algae which may not represent an optimal food resource. Presumably, additional experiments with a variety of FLA would broaden the range of uptake rates and provide even more favorable comparisons.

FLA uptake can also be used for larval stages of crustacean zooplankton. Stage III nauplii of the barnacle Balanus improvisus which had been starved for $2 \mathrm{~h}$ rapidly consumed fluorescently labelled Tetraselmis suecica. Stage IV nauplii of the barnacle Balanus eburneus incorporated, on average, 2.7 (SD 2.6) labelled
Fig. 4. Selectivity of Brachionus sp. for Nannochloris FLA vs autofluorescent particles. Solid line: regression of FLA uptake vs fraction of FLA in algal mixture; dashed line: regression of total algal cell uptake (cells per individual/fraction of FLA) vs fraction of FLA.

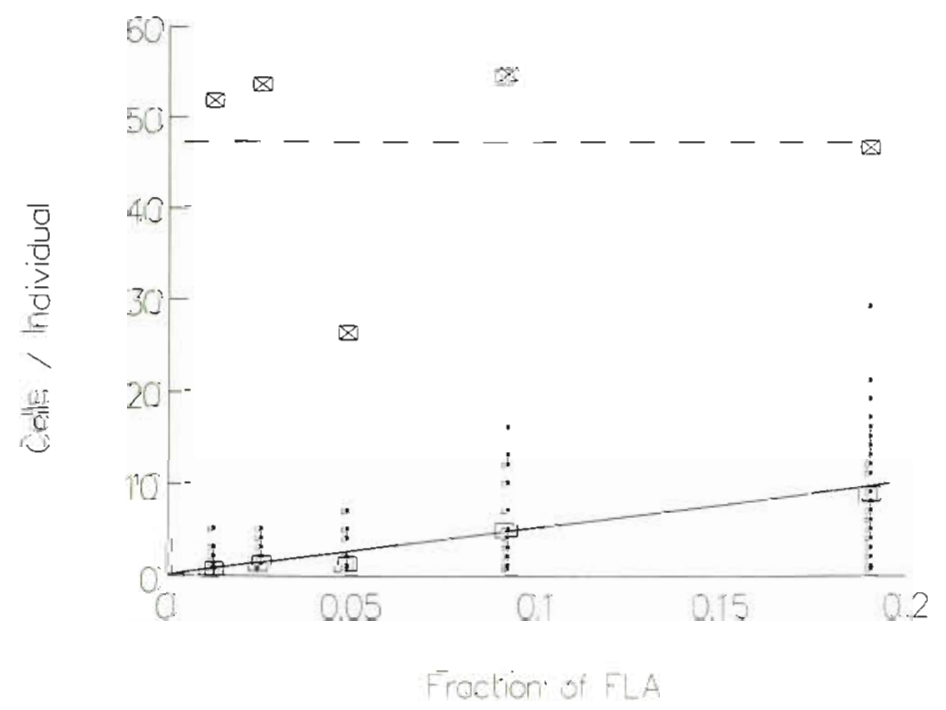


Table 2. Clearance rates of microplankton estimated by various methods

\begin{tabular}{|c|c|c|c|}
\hline Organism & $\begin{array}{l}\text { Clearance rate } \\
\left(\mu \mathrm{l} \text { cell }^{-1} \mathrm{~h}^{=1}\right)\end{array}$ & Method & Reference \\
\hline \multicolumn{4}{|l|}{ Ciliates } \\
\hline Dinoflagellates & $0.5-28.3$ & Dual label: ${ }^{3} \mathrm{H}_{1}{ }^{14} \mathrm{C}$ & Lessard \& Swift (1985) \\
\hline \multirow[t]{6}{*}{ Non-loricate ciliates } & $0-12$ & FLA & This study \\
\hline & $0.7-213$ & Dual label: ${ }^{3} \mathrm{H}^{14} \mathrm{C}$ & Lessard \& Swift (1985) \\
\hline & $1-11$ & Pigment dilution assay & Burkill et al. (1987) \\
\hline & $0.6-40$ & Uptake of bacteria & Rivier et al. (1985) \\
\hline & $0.52-26$ & Latex microspheres & Jonsson (1986) \\
\hline & $0.14-32$ & FLB & Sherr et al. (1987) \\
\hline \multirow[t]{6}{*}{ Tintinnids } & $0-3$ & \multirow{6}{*}{$\begin{array}{l}\text { FLA } \\
\text { Dual label: }{ }^{3} \mathrm{H},{ }^{14} \mathrm{C} \\
\text { Count ingested algae } \\
\text { Count ingested yeast } \\
\text { Phytoplankton disappearance } \\
\text { Ingested starch granules } \\
\text { Phytoplankton disappearance }\end{array}$} & This study \\
\hline & $0.6-32$ & & Lessard \& Swift (1985) \\
\hline & $0.5-38$ & & Spittler (1973) \\
\hline & $0.5-38$ & & Blackbourn $(1974\}$ \\
\hline & $1-10$ & & Heinbokel (1978) \\
\hline & $1-85$ & & Capriulo \& Carpenter (1980) \\
\hline \multicolumn{4}{|l|}{ Rotifers } \\
\hline Brachionus sp. & $0-12.5$ & FLA & This study \\
\hline Brachionus sp. & $0-50$ & Radiolabelled algae & Starkweather \& Gilbert (1972) \\
\hline Polyarthra/Keratella & $0.1-155$ & Radiolabelled algae & Bogdan \& Gilbert (1984) \\
\hline 8 rotifer spp. & $0-6$ & Radiolabelled bacteria/algae & Bogdan et al. (1980) \\
\hline
\end{tabular}

Prorocentrum mariae-laboriae cells over 20 min. Are even larger zooplankters amenable to this technique? We have not tested larger organisms, but suspect that even if larger algae are used, the thick tissues of larger consumers will make it difficult to discriminate the labelled algal cells.

Sherr et al. (1988) used disappearance of ingested FLB as a measure of digestion of bacteria in flagellates and ciliates, and FLA digestion can probably be assessed in a similar manner. In our rotifer experiments, the ingested FLA in some individuals were difficult to count after $60 \mathrm{~min}$ of incubation because the fluorescence of the algal cells was less bright and the algae appeared smaller. Presumably this was due to digestion of the algal cells and release of the fluorescently labelled cytoplasm.

There was a high degree of variability in uptake of FLA by consumer populations. At each time interval some individual grazers lacked any ingested FLA, while others had many algal cells. The variance was equal to or larger than the mean rate of uptake. Such individual variability may be viewed as a strength of the method for answering some questions. For example, information on individual uptake rates over short time-course experiments may yield insight into feeding response curves, feeding strategies, diurnal activity, and how feeding activities are related to the predator or prey cell cycle.

Prey selectivity may also be addressed through the use of FLA and FLB. As long as they have visually distinct morphologies, multiple types of DTAF labelled cells can be added in a single incubation. Thus, by adjusting the mixture and concentrations of prey items, a picture of prey preferance under varying conditions could be determined.

The method as described here would be difficult to use for estimation of community grazing rates for 2 reasons. First, this would require observation of a large number of individuals of various taxa, a tedious task. Automated methods of counting, such as flow cytometry or the use of image analysis systems, or fluorometric analysis of the dye after removal of unincorporated FLA and extraction of the fluorochrome from biota in a manner analogous to that used for chlorophyll may circumvent this problem. The second reason is that sample manipulations may be a source of variability through damage or incomplete filtration. This problem is resolvable by the use of in situ incubations conducted in diffusion culture chambers or Haney chambers (e.g. Roman \& Rublee 1981) with added FLA. We are currently examining the suitability of such methods.

Much remains to be learned about microzooplankton grazing and its significance in food webs. Recent papers note that feeding response of microzooplankton can be dependent upon size, quality, and concentration of food resources (e.g. Bogdan \& Gilbert 1984, 1987 , Anderson et al. 1986, Jonsson 1986, Sherr et al. 1987, Sibbauld et al. 1987). The utilization of a fluorescent tag to determine short-term uptake rates of algae should prove a useful addition to the methods available for grazing studies. 
Acknowledgements. We thank Drs Barry and Evelyn Sherr for discussion of the FLB procedure, Dr Thomas Jordan for critical comments and discussion during this study, and Dr W. K. W. Li for providing a Synechococcus culture. This work was conducted under a senior postdoctoral fellowship awarded by the Office of Fellowships and Grants, Smithsonian Institution, to P.A.R

\section{LITERATURE CITED}

Andersson, A., Larsson, U., Hagström, A. (1986). Size-selective grazing by a microflagellate on pelagic bacteria. Mar Ecol. Prog. Ser. 33: 51-57

Azam, F., Fenchel, T., Field, J. G., Gray, J. S., Meyer-Reil, L.-A., Thingstad, F. (1983). The ecological role of watercolumn microbes in the sea. Mar. Ecol. Prog. Ser. 10: 257-263

Baldock, B. M. (1986). A method for enumerating protozoa in a variety of freshwater habitats. Microb. Ecol. 12: 187-191

Blackbourn, D. J. (1974). The feeding biology of tintinnid Protozoa and some other inshore microzooplankton. Ph.D. thesis, Univ. of British Columbia

Bogdan, K. G., Gilbert, J. J. (1984). Body size and food size in freshwater zooplankton. Proc. natl Acad. Sci. U.S.A. 81. $6427-6431$

Bogdan, K. G., Gilbert, J. J. (1987). Quantitative comparison of food niches in some freshwater zooplankton: a multitracer-cell approach. Oecologia (Berl.) 72: 331-340

Bogdan, K. G., Gilbert, J. J., Starkweather, P. L. (1980). In situ clearance rates of planktonic rotifers. Hydrobiologia 73: 73-77

Borsheim, K. Y (1984). Clearance rates of bacteria sized particles by freshwater ciliates, measured with monodispersed fluorescent latex beads. Oecologia (Berl.) 63: $286-288$

Burkhil, P. H., Mantoura, R. F. C., Llewellyn, C. A., Owens, N. J. P. (1987). Microzooplankton grazing and selectivity of phytoplankton in coastal waters. Mar. Biol. 93: 581-590

Capriulo, G. M. Carpenter, E. J. (1980). Grazing by the 35 to $202 \mu \mathrm{m}$ micro-zooplankton in Long Island Sound. Mar Biol. 56: 319--326

Ducklow, H. W. Hill, S. M. (1985). The growth of heterotrophic bacteria in the surface waters of warm core rings. Limnol. Oceanogr. 30: 239-259

Heinbokel, J. F. (1978). Studies on the functional role of tintinnids in the Southern California Bight. I. Grazing and growth rates in laboratory cultures. Mar Biol. 47: 177-189

Jonsson, P. R. (1986). Particle size selection, feeding rates and growth dynamics of marine planktonic oligotrichous ciliates (Ciliophora: Oligotrichina). Mar. Ecol. Prog. Ser. 33: $265-277$
Landry, M. R., Hassett, R. P. (1982). Estimating the grazing impact of marine microzooplankton. Mar. Biol. 67. $283-288$

Lessard, E. J.. Swift. E. (1985). Species-specific grazing rates of heterotrophic dinoflagellates in oceanic waters, measured with a dual-label radioisotope technique. Mar. Biol. 87: 289-296

McManus, G. B., Fuhrman, J. A. (1986). Bacterivory in seawater studied with the use of inert fluorescent particles. Limnol. Oceanogr 31:420-426

McManus, G. B., Fuhrman, J. A. (1988). Control of bacterioplankton populations: measurement and significance of grazing. Hydrobiologia 159: 51-62

Newell, S. Y., Sherr, B. F., Sherr, E. B., Fallon, R. D. (1983). Bacterial response to the presence of eukaryotic inhibitors in water from a coastal marine environment. Mar. environ. Res. 10: 147-157

Pace, M. L., Bailiff, M. D. (1987). Evaluation of a fluorescent microsphere technique for measuring grazing rates of phagotrophic microorganisms. Mar. Ecol. Prog. Ser. 40: $185-193$

Peterson, B. J., Hobbie, J. E., Haney, J. F. (1978). Daphnia grazing on natural bacteria. Limnol. Oceanogr 23 1039-1044

Pomeroy, L. R., Wiebe, W. J. (1988). Energetics of microbial food webs. Hydrobiologia 159: 7-18

Rivier, A., Brownlee, D. C., Sheldon, R. W., Rassoulzadegan, F. (1985). Growth of microzooplankton: a comparative study of bacterivorous zooflagellates and ciliates. Mar microb. Food Webs 1 51-60

Roman, M. R., Rublee, P. A. (1981). A method to determine in situ zooplankton grazing rates on natural particle assemblages. Mar Biol. 65: 303-309

Sherr, B. F., Sherr, E. B., Fallon, R. D. (1987). Use of monodispersed, fluorescently labelled bacteria to estimate in situ protozoan bacterivory. Appl. environ. Microbiol. 53: 958-965

Sherr, B. F., Sherr, E. B., Rassoulzadegan, F. (1988). Rates of digestion of bacteria by marine phagotrophic Protozoa: temperature dependence. Appl. environ. Microbiol. 54: 1091-1095

Sibbald. M. J., Albright, L. J., Sibbauld, P. R. (1987). Chemosensory responses of a heterotrophic microflagellate to bacteria and several nitrogen compounds. Mar. Ecol. Prog. Ser 36: 201-204

Spittler, P. (1973). Feeding experiments with tintinnids. Oikos (Suppl.) 15: 128-132

Starkweather, P. L., Gilbert, J. J. (1972). Feeding in the rotifer Brachionus calyciflorus II. Effect of food density on feeding rates using Euglena gracilis and Rhodotorula glutinis. Oecologia (Berl.) 28: 133-139 